\title{
Delineation of management zones with soil apparent electrical conductivity to improve nutrient management ${ }^{\text {tr }}$
}

\author{
Nahuel Raúl Peralta ${ }^{\mathrm{a}, \mathrm{c}, *}$, José Luis Costa ${ }^{\mathrm{b}, \mathrm{c}}$ \\ ${ }^{a}$ Consejo Nacional de Investigaciones Científicas y Técnicas (CONICET), Av. Rivadavia 1917, CP C1033AAJ, Buenos Aires, Argentina \\ ${ }^{\mathrm{b}}$ Estación Experimental Agropecuaria INTA, Balcarce C.C.276, 7620 Balcarce, Buenos Aires, Argentina \\ ${ }^{\mathrm{c}}$ Facultad de Ciencias Agrarias-UNMdP (Universidad Nacional de Mar del Plata), Unidad Integrada Balcarce, C.C.276, 7620 Balcarce, Buenos Aires, Argentina
}

\section{A R T I C L E I N F O}

\section{Article history:}

Received 13 May 2013

Received in revised form 17 September 2013 Accepted 30 September 2013

\section{Keywords:}

Precision agriculture

Management zones

Spatial variability

Soil properties

Nutrient concentrations

\begin{abstract}
A B S T R A C T
Site-specific management demands the identification of subfield regions with homogeneous characteristics (management zones). However, determining subfield areas is difficult because of complex correlations and the spatial variability of soil properties and nutrient concentrations, responsible for variations in crop yields within the field. We evaluated whether apparent electrical conductivity $\left(\mathrm{EC}_{\mathrm{a}}\right)$ is a potential estimator of soil properties and nutrients, and a tool for the delimitation of homogeneous zones. Two field sites with several soil series were studied in southeastern Cordoba Province, Argentina. Soil properties and nutrient concentrations were compared with $\mathrm{EC}_{\mathrm{a}}$ using principal components (PC)stepwise regression and ANOVA. The PC-stepwise regression showed that soil properties $\left(\mathrm{pH}, \mathrm{EC}_{1: 2.5}\right.$, CEC, SOM) and nutrients $\left(\mathrm{Na}^{+2}, \mathrm{Mg}^{+2}, \mathrm{Mn}^{+2}, \mathrm{Cu}^{+2}, \mathrm{Ca}^{+2}, \mathrm{Zn}^{+2}, \mathrm{Fe}^{+2}\right.$ ) are key loading factors to explain the $\mathrm{EC}_{\mathrm{a}}\left(R^{2}>0.90\right)$. In contrast, $\mathrm{K}^{+}, \mathrm{P}, \mathrm{NO}_{3}^{-}-\mathrm{N}$ and $\left.\mathrm{SO}_{4}^{-2}-\mathrm{S}\right)$, content were not able to explain the $\mathrm{EC}_{\mathrm{a}}$. The ANOVA showed that $\mathrm{EC}_{\mathrm{a}}$ measurements successfully delimited two homogeneous soil zones associated with the spatial distribution of soil properties and some nutrients $\left(\mathrm{Na}^{+2}, \mathrm{Mg}^{+2}, \mathrm{Mn}^{+2}, \mathrm{Cu}^{+2}, \mathrm{Ca}^{+2}, \mathrm{Zn}^{+2}\right.$, $\mathrm{Fe}^{+2}$ ). These results suggest that field-scale $\mathrm{EC}_{\mathrm{a}}$ maps have the potential to design sampling zones to implement site-specific management strategies.
\end{abstract}

(c) 2013 Elsevier B.V. All rights reserved.

\section{Introduction}

The Cordoba Province of Argentina is a vast plain with approximately 7.794 (miles ha) of cropland. This province is the largest producer of soybeans and corn in Argentina, producing 12,750 ('000 ton) and 8749 ('000 ton), respectively (SAGPyA, 2009), and is composed mainly of (I) excessively drained soils, developed on sandy materials related to higher areas of land with a use capacity (usability) limited by low moisture retention (Instituto Nacional de Tecnología Agropecuaria (INTA), 1986) and (II) moderately drained to imperfect soils, moderately saline-alkali in depth, developed on sandy-loam to loam materials, related to depressed areas of land. Its usability is restrained by the presence of salts, which limits grain production. Soils vary widely in their nutrient contents and in their ability to supply sufficient micronutrients for optimal crop production. The spatial variability of soil nutrients may be affected

\footnotetext{
is This is an open-access article distributed under the terms of the Creative Commons Attribution-NonCommercial-No Derivative Works License, which permits non-commercial use, distribution, and reproduction in any medium, provided the original author and source are credited.

* Corresponding author at: Facultad de Ciencias Agrarias-UNMdP (Universidad Nacional de Mar del Plata), Unidad Integrada Balcarce, C.C.276, 7620 Balcarce, Buenos Aires, Argentina. Tel.: +54 2266 439100; fax: +54 02266439101.

E-mail address: nperalta21@gmail.com (N.R. Peralta).
}

by soil type, land forms, vegetation, climate, and anthropogenic activities. Therefore, it is not surprising that the content, distribution, and availability of soil nutrients can vary widely among soils both within and between fields (Corwin and Lesch, 2003).

Uniform management of fields does not take into account the spatial variability; therefore, it is not the most effective management strategy (Moral et al., 2010). Precision agriculture is considered the most viable approach for achieving sustainable agriculture (Kravchenko and Bullock, 2002; Bullock et al., 2007). In particular, site-specific management (SSM) is a form of precision agriculture whereby decisions on resource application and agronomic practices are improved to better match soil and crop requirements as they vary in the field. SSM enables the identification of regions (management zones) within the area delimited by field boundaries. These subfield regions constitute areas of the field that have similar permanent characteristics, such as topography and nutrient levels (Kitchen et al., 2005; Moral et al., 2011).

Efficient techniques to accurately measure within-field variations in soil properties are very important for homogeneous management zones (HMZ) (Peralta et al., 2013). Traditional soil sampling is costly and labor-intensive. This traditional method is not viable from an HMZ perspective, because it needs a large number of soil samples in order to achieve a good representation of soil properties and nutrient levels. The geospatial measurement of $\mathrm{EC}_{\mathrm{a}}$ 
is an efficient ground-based sensing technology that is helping to take HMZ from concept to reality (Corwin and Lesch, 2003). EC can be intensively recorded in an easy and inexpensive way, and it is usually related to various physico-chemical properties across a wide range of soils (Sudduth et al., 2005), because it depends on the chemical composition of the soil solution and soil exchangeable ions, clay content, and the interaction between non-exchangeable and exchangeable ions (Rhoades et al., 1989). This methodology can improve the characterization of the spatial pattern of edaphic properties that influence the nutrient content of the soil, which in turn can be used to define SSM units (Moral et al., 2010). However, the $\mathrm{EC}_{\mathrm{a}}$ applications in $\mathrm{HMZ}$ showed weak and inconsistent relationships between $\mathrm{EC}_{\mathrm{a}}$ and soil characteristics (Corwin and Lesch, 2003; Sudduth et al., 2005). These inconsistent relationships may be generated by the potentially complex interrelationships between $\mathrm{EC}_{\mathrm{a}}$ and soil characteristics (soil properties and nutrient levels). The delimitation of $\mathrm{HMZ}$ with $\mathrm{EC}_{\mathrm{a}}$ measurement to improve nutrient management has not been adequately described for excessively drained soils and moderately drained to imperfect soils (with salts present), which are characteristic of many agriculturally important soils in Argentina and throughout the world.

The main aims of this paper are to determine: (I) whether fieldscale $\mathrm{EC}_{\mathrm{a}}$ geospatial measurement is a potential estimator of soil properties $\left(\mathrm{EC}_{1: 2.5}, \mathrm{pH}, \mathrm{SOM}\right.$ and $\left.\mathrm{CEC}\right)$ and nutrient levels $\left(\mathrm{P}, \mathrm{Zn}^{+2}\right.$, $\mathrm{Ca}^{+2}, \mathrm{Mg}^{+2}, \mathrm{Mn}^{+2}, \mathrm{Na}^{+}, \mathrm{K}^{+}, \mathrm{Fe}^{+2}, \mathrm{Cu}^{+2}, \mathrm{NO}_{3}-\mathrm{N}$ and $\mathrm{SO}_{4}^{-2}-\mathrm{S}$ ) and (II) whether $\mathrm{EC}_{\mathrm{a}}$ measurement can enable the delimitation of $\mathrm{HMZ}$ within the field of production. If $\mathrm{EC}_{\mathrm{a}}$ could be used to produce accurate maps of zones with the differences in the soil properties and nutrient concentrations indicated, it could be a useful tool for variable-rate seeding and for fertilizer producers.

\section{Materials and methods}

\subsection{Experimental sites}

Soil EC $\mathrm{C}_{\mathrm{a}}$ mapping was carried out in July of 2009 and soil samples were taken prior to sowing winter crops (wheat, Triticum aestivum).

This study was conducted on two fields at La Unión, in southeastern Cordoba Province, Argentina (Fig. 1). The fields were 39 ha (F1) and 25 ha (F2) in size, cultivated under a no-tillage system since the year 2002 using a soybean-corn rotation system during the summer cropping seasons and with wheat as a cover crop during the winter season.

The soils in the two fields include a Canals series (coarse-loamy, mixed, thermic, Entic Haplustoll), an Aromos series (coarse-loamy, mixed, thermic, Typic Calciacuoll) and Medanitos series (coarseloamy, mixed, thermic, Typic Natralboll). The Canals series is a well-drained soil, developed on sandy materials associated with hills. The Aromos and Medanitos series are moderate to imperfect-drainage soils, moderately saline-alkali in depth, developed on sandy-loam to loam materials linked to depressed levels. The climate of this region is characterized by a thermal regime with a mean annual temperature of $17^{\circ} \mathrm{C}$ and a variation of $14^{\circ} \mathrm{C}$. Average annual rainfall is $871 \mathrm{~mm}$ and the seasonal distribution is a monsoon type (Ghida Daza and Sánchez, 2009).

\subsection{Soil $E C_{a}$ and elevation data collection}

Soil EC $\mathrm{a}_{\mathrm{a}}$ measurements were made using the Veris $3100^{\circledR}$ (Veris 3100, Division of Geoprobe Systems, Salina, KS) (Fig. 2b). The device comprises six disc-shaped metal electrodes (coulter), which penetrate approximately $6 \mathrm{~cm}$ into the soil. One pair of electrodes passes electrical current into the soil, while the other two pairs measure the voltage drop. The measurement depth is based on the distance between the emitting and receiving coulter-electrodes. The system is set up to work in configuration $A(0-30 \mathrm{~cm})$ and $B(0-90 \mathrm{~cm})$ (Fig. 2a). Configuration A comprises the inside coulters $(2,3,4,5)$ and voltage is measured between the innermost ones ( 3 and 4 ). In configuration B, the four outside coulters $(1,2,5$, 6 ) include the $0-90 \mathrm{~cm}$ deep measurement, and the voltage gradient is measured between coulters 2 and 5 (Fig. 2a). Output from the Veris data logger reflects the conversion of resistance to conductivity $(1 /$ resistance $=$ conductivity $)$. In this paper, we are working with an $\mathrm{EC}_{\mathrm{a}}$ measurement to $0-90 \mathrm{~cm}$ because it is more stable over time than the $\mathrm{EC}_{\mathrm{a}}$ to $0-30 \mathrm{~cm}$ (Veris Technologies, 2001; Sudduth et al., 2003). The Veris 3100 sensor was pulled across each field behind a pick-up truck, taking simultaneous and geo-referenced $\mathrm{EC}_{\mathrm{a}}$ measurements in real-time with a differential GPS (Trimble 132, Trimble Navigation Limited, USA) (Fig. 2), with sub-meter measurement accuracy and configured to take a satellite position once per second. On average, travel speeds through the field mapping ranged between 7 and $11 \mathrm{~km} \mathrm{~h}^{-1}$, corresponding to about 2-3 $\mathrm{m}$ spacing between measurements in the direction of travel. For ease of maneuvering, the field was traversed in the direction of crop rows in a series of parallel transects spaced at 15 - to $30-\mathrm{m}$ intervals, because a spacing greater than $30 \mathrm{~m}$ generates measurement errors and information loss (Farahani and Flynn, 2007). Elevation dates were collected at the same times that $\mathrm{EC}_{\mathrm{a}}$ data, using a differential GPS (vertical accuracy of 3-5 cm).

\subsection{Electrical conductivity zones and determination of sampling points}

Previous research on various soils suggested that using more than three zones does not increase the available information (Peralta et al., 2013). Therefore, soil sampling was carried out by zones, based on three $\mathrm{EC}_{\mathrm{a}}$ classes. Soil $\mathrm{EC}_{\mathrm{a}}$ values and amplitude were classified by equal area quantiles using the Geostatistical Analyst in ArcGIS 9.3.1 (Environmental System Research Institute, Redlands, CA). Three representative geo-referenced soil-sampling points were selected within each of the three $\mathrm{EC}_{\mathrm{a}}$ classes identified at each field (Fig. 3). Soil sample data were matched to the $\mathrm{EC}_{\mathrm{a}}$ measurements taken using the Veris 3100 by averaging all $\mathrm{EC}_{\mathrm{a}}$ measurements from the portion of the transect within a $20-\mathrm{m}$ radius of the center-point location from which the soil cores were collected. This resulted in an average of eight to ten $\mathrm{EC}_{\mathrm{a}}$ measurements matched to each soil sample taken.

\subsection{Soil sampling and analysis}

Soil samples were collected in plastic bags. Upon arrival at the laboratory, they were air-dried and analyzed for soil organic matter (SOM) by dichromate oxidation (Walkley and Black, 1934). Cation exchange capacity (CEC) was measured using the neutral ammonium acetate method; $\mathrm{pH}$ in a 1:2.5 (soil:water) suspension and the electrical conductivity of saturation extract $\left(\mathrm{EC}_{1: 2.5}\right)$ was measured using the electrometric method (Chapman, 1965). The $\mathrm{NO}_{3}^{-}-\mathrm{N}$ content was determined with the colorimetric method of acid 2,4 phenoldisulfonic (Bremner, 1965). $\mathrm{P}, \mathrm{Zn}^{+2}, \mathrm{Ca}^{+2}, \mathrm{Mg}^{+2}$, $\mathrm{Mn}^{+2}, \mathrm{Na}^{+}, \mathrm{K}^{+}, \mathrm{Fe}^{+2}, \mathrm{Cu}^{+2}, \mathrm{SO}_{4}^{-2}$ were quantified by extracting the soil solution with Mehlich-3 extractant (Mehlich, 1984) and analyzing the elements with a PerkinElmer Plasma System (PerkinElmer, Wellesley, MA).

\subsection{Spatial variability of $E C_{a}$ and elevation}

The spatial dependence of $\mathrm{EC}_{\mathrm{a}}$ and the elevation were quantified using semivariograms which characterize and determine distribution patterns such as randomness, uniformity and spatial trend. 


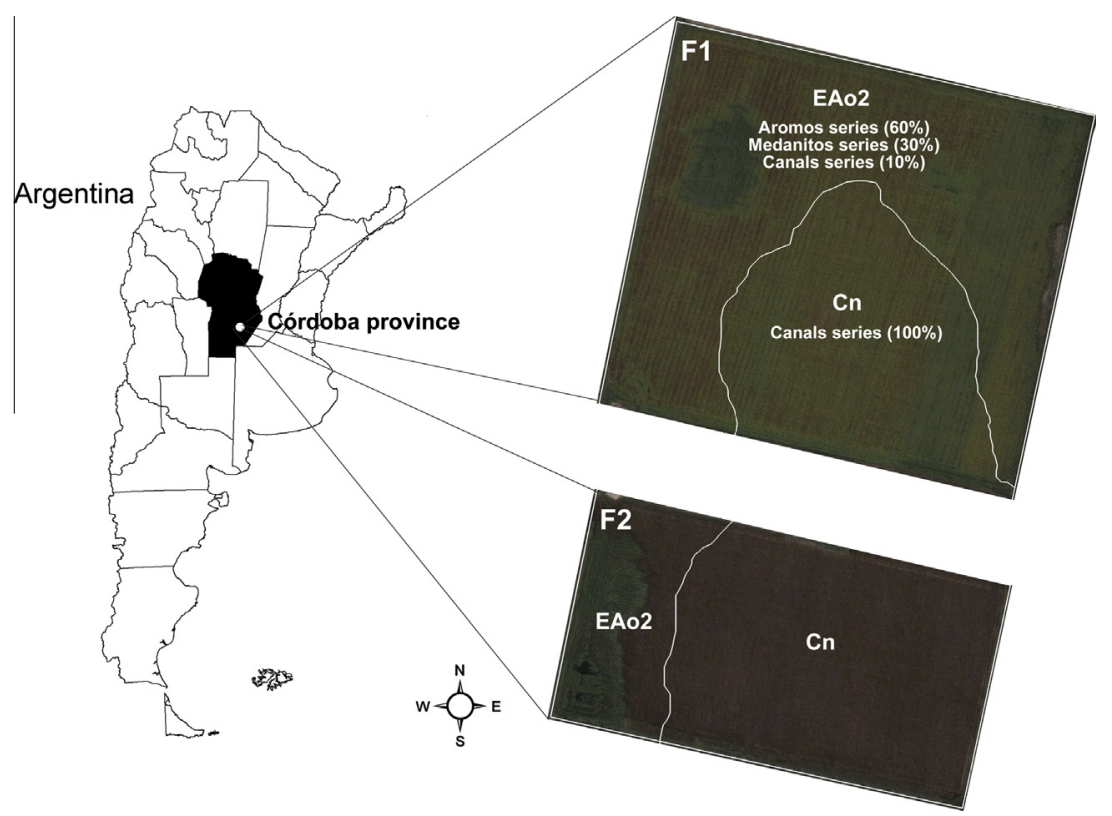

Fig. 1. Soil series for the two fields, situated in southeastern Cordoba Province, Argentina.

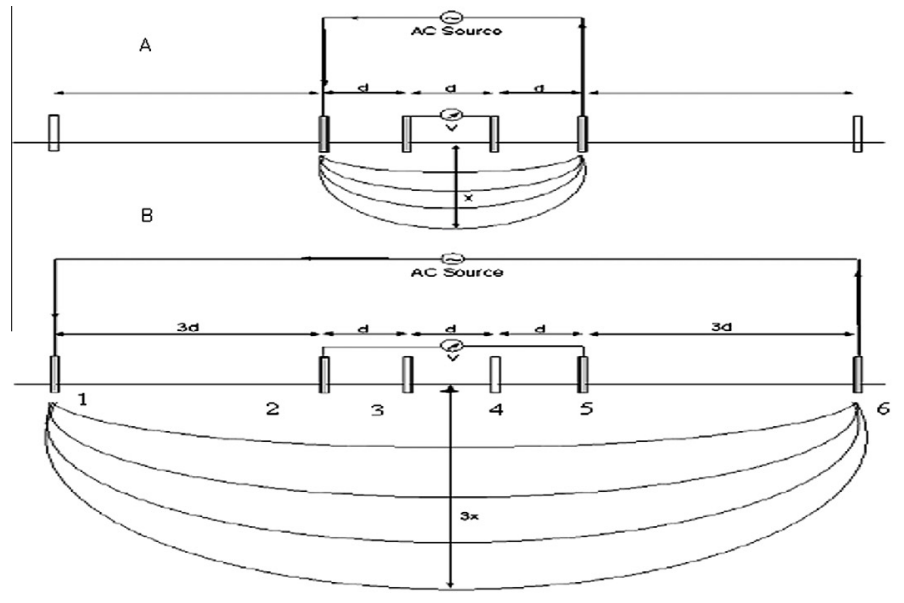

(a)

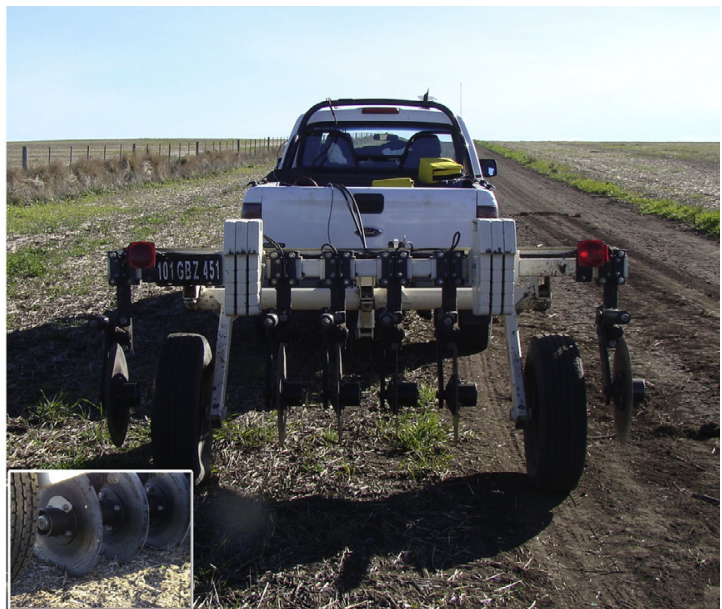

(b)

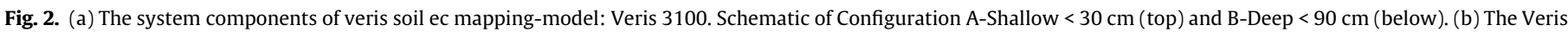
3100 Mapping System mounted behind truck.

The semivariogram was estimated using the equation (Isaaks and Srivastava, 1989):

$\gamma^{*}(h)=\frac{1}{2 N(h)} \sum_{i=1}^{N(h)}\left(z\left(x_{i}\right)-z\left(x_{i}+h\right)\right)^{2}$

where $\gamma^{*}(h)$ is the experimental semivariance value at distance interval $h ; z\left(x_{i}\right)$ is the measured sample value at sample points $x_{i}$, in which there are data at $x_{i}$; and $x_{i}+h ; N(h)$ is the total number of sample pairs within the distance interval $h$. The semivariogram shows the decrease of spatial correlation between two points in space when the separation distance increases. The semivariograms adjusted for each field were used to interpolate the $\mathrm{EC}_{\mathrm{a}}$ and elevation by means of ordinary kriging after checking geo-statistical common assumptions (Isaaks and Srivastava, 1989), using ArcGIS Geospatial Analyst (ArcGIS v9.3.1, Environmental System Research Institute Inc. (ESRI), Redlands, CA, USA). A final $10 \mathrm{~m} \times 10 \mathrm{~m}$ grid cell size was chosen because it reflects the scale of variability asso- ciated with the $\mathrm{EC}_{\mathrm{a}}$ measurements and elevation (Kitchen et al., 2003).

\subsection{Statistical analysis}

Principal-components analysis was used to examine the relationship between the soil properties $\left(\mathrm{EC}_{1: 2.5}, \mathrm{pH}, \mathrm{MOS}\right.$ and $\mathrm{CEC}$ ) and nutrient levels measured in this study $\left(\mathrm{P}, \mathrm{Zn}^{+2}, \mathrm{Ca}^{+2}, \mathrm{Mg}^{+2}\right.$, $\mathrm{Mn}^{+2}, \mathrm{Na}^{+}, \mathrm{K}^{+}, \mathrm{Fe}^{+2}, \mathrm{Cu}^{+2}, \mathrm{NO}_{3}-\mathrm{N}$ and $\left.\mathrm{SO}_{4}^{-2}-\mathrm{S}\right)$, and to determine which soil properties and nutrients were important influences on $\mathrm{EC}_{\mathrm{a}}$.

Due to the colinearity of the independent variables, correlation analysis could not be used to directly relate multiple soil properties to $\mathrm{EC}_{\mathrm{a}}$. Principal components analysis puts identified, correlated variables into groups. These groups (PCs) become new, independent, random variables that could then be used to identify which soil properties influenced $\mathrm{EC}_{\mathrm{a}}$. In this study, the objectives of using the PC-stepwise regression analysis were to identify the key soil 


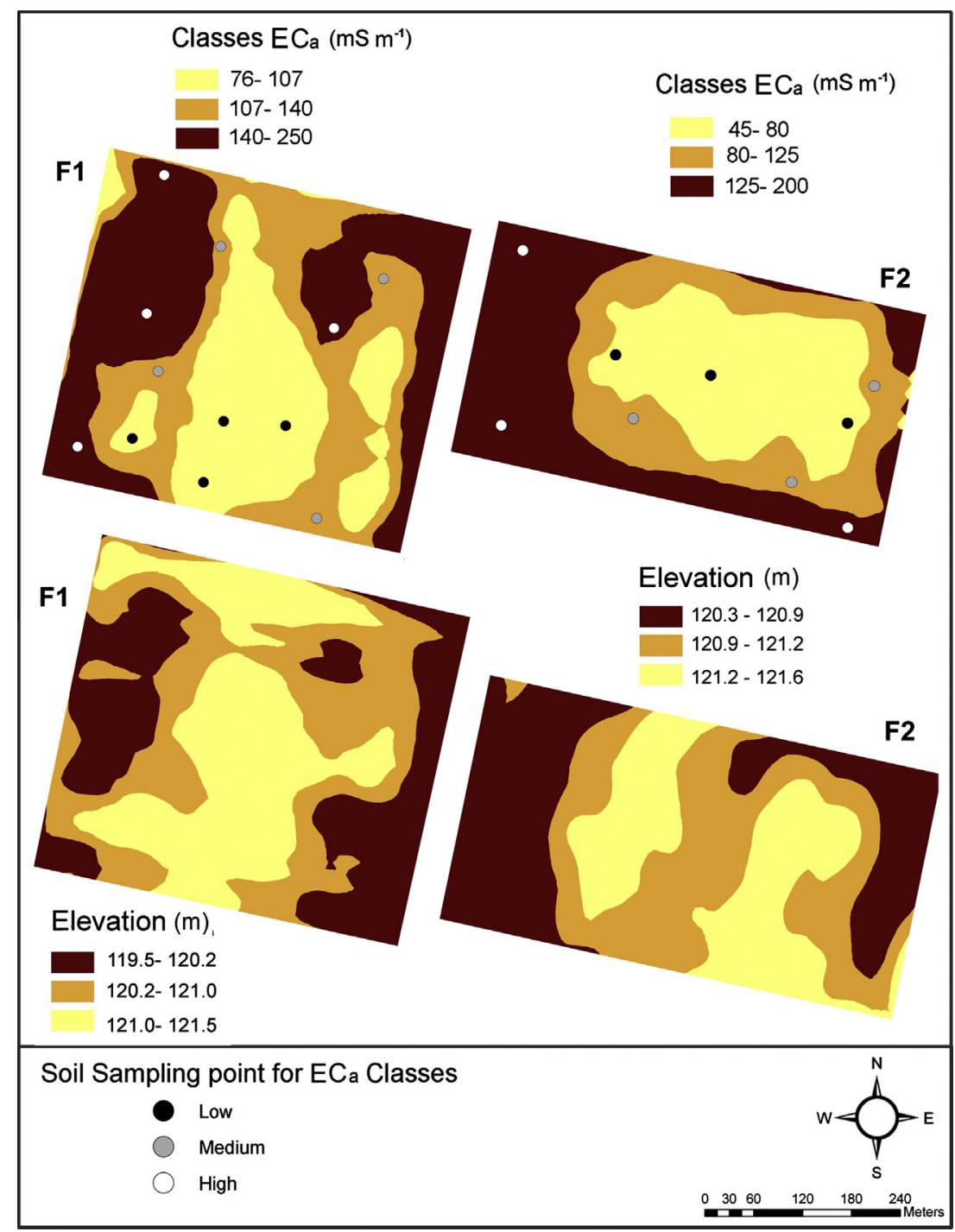

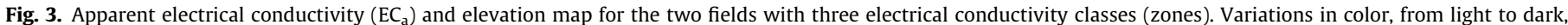
correspond to increasing conductivity.

properties and nutrients that had significant relationships with $\mathrm{EC}_{\mathrm{a}}$; determine the strength of that relationship; and determine the influence and role of each soil property and nutrient in the relationship.

The PCs were identified from the correlation matrix using the COMP procedure in SAS (SAS Institute, 2002). Any PCs with an eigenvalue greater than 1 was selected because it explained a significant amount of the variance present in the soil properties and nutrients at each field. The PCs with eigenvalues $>1$ were then used in a stepwise-regression procedure (SAS Institute, 2002) to determine if there was a significant relationship between the $\mathrm{PCs}$ and $\mathrm{EC}_{\mathrm{a}}$. The stepwise-regression procedure repeatedly alters the model by adding or removing predictor PCs until the only remaining PCs are above the 0.15 significance level. The regression therefore effectively evaluates the result of the PCA. When the PCs remaining in the regression model accounted for $>50 \%$ of the variability in the $\mathrm{EC}_{\mathrm{a}}$ measurement, the eigenvectors (loading factors) were examined and the soil properties-nutrients in the PCs ranked according to the amount of variability explained by the PCs. For instance, a soil property and nutrient that was a component of the PCs that accounted for most of the variability in the regression model and had the highest loading factor in that
PC group was ranked first. Soil properties and nutrients with loading factors $<0.4$ were not considered key latent variables and were not included in the ranking because they did not substantially influence the relationship between the PC groups and the nutrient concentration being examined. The ranking of the soil properties and nutrients, strength of the loading factor, and sign (positive or negative) of the loading factor were used to determine the influence and role that each soil property and nutrient had in explaining the variability in the $\mathrm{EC}_{\mathrm{a}}$.

In order to determine whether the $\mathrm{EC}_{\mathrm{a}}$ measurements allow delimitation of homogeneous zones within the fields, the differences in the averages of the soil properties (SOM, CEC, EC $\mathrm{E}_{1: 2.5}$, $\mathrm{pH}_{\mathrm{s}}$ ) and the amount of nutrients $\left(\mathrm{P}, \mathrm{Zn}^{+2}, \mathrm{Ca}^{+2}, \mathrm{Mg}^{+2}, \mathrm{Mn}^{+2}, \mathrm{Na}^{+}\right.$, $\mathrm{K}^{+}, \mathrm{Fe}^{+2}, \mathrm{Cu}^{+2}, \mathrm{NO}_{3}^{-}-\mathrm{N}$ and $\mathrm{SO}_{4}^{-2}$ ) were compared among the various $\mathrm{EC}_{\mathrm{a}}$ classes (zones) using a mixed ANOVA model from PROC MIXED (SAS Institute, 2002). They were compared using the LSMEANS procedure of PROC MIXED (SAS Institute 2002), with a significance level of 0.05. Descriptive statistics and simple correlations between the soil properties-nutrients and $\mathrm{EC}_{\mathrm{a}}$ were calculated using the SAS MEANS and CORR procedures (SAS Institute 2002). Significant results with a high Pearson correlation coefficient $(>0.60)$ indicate situations where the $\mathrm{CE}_{\mathrm{a}}$ measured could be used to estimate soil 
properties and the concentration of a particular element in the soil (Heiniger et al., 2003).

\section{Result and discussion}

\subsection{Exploratory analysis of $E C_{a}$, soil properties and nutrient concentrations}

Maps of $\mathrm{EC}_{\mathrm{a}}$ and elevation are shown for F1 and F2 (Fig. 3), and the associated descriptive statistics are summarized in Table $1 . \mathrm{EC}_{\mathbf{a}}$ measurements showed substantial spatial variability with CV varying from $38.97 \%$ to $53.63 \%$ across the two studied fields. Mean $\mathrm{EC}_{\mathrm{a}}$ measurements for F1 were notably greater than for F2. These differences in mean $\mathrm{EC}_{\mathrm{a}}$ might be caused by the greater proportion of Aromos and Medanitos series within F1. These series had higher salt content values (higher $\mathrm{EC}_{1: 2.5}$ ) and clay content than the Canals series. In the model proposed by Rhoades et al. (1989), they identified that the major factors that influence $\mathrm{EC}_{\mathrm{a}}$ are: (I) the electrical conductivity of the soil solution associated with continuous and discontinuous pores; (II) the volumetric content of soil particles; (III) the electrical conductivity of the soil particles and; (IV) the volumetric water content in the soil. The first, second and third factor are influenced and increased by soil salinity (Malicki and Walczak, 1999), clay content (Rhoades and Corwin, 1990), and CEC (Shainberg et al., 1980), respectively. With respect to the fourth factor, the conduction of electricity in soils takes place through moisturefilled pores between soil particles; soils with high clay content generally have more continuous water-filled pores that tend to

\section{Table 1}

Summary statistics of apparent electrical conductivity $\left(\mathrm{EC}_{\mathrm{a}}\right)$, elevation, soil properties and nutrient concentrations in each field. Average values (mean), coefficient of variation $(\mathrm{CV})$, minimum (min), maximum (max) and range.

\begin{tabular}{|c|c|c|c|c|c|c|}
\hline Fields & Variables & Mean & $\mathrm{CV}$ & Min & Max & Range \\
\hline \multirow{14}{*}{ F1 } & $\mathrm{EC}_{\mathrm{a}}\left(\mathrm{mS} \mathrm{m}^{-1}\right)$ & 139.27 & 38.97 & 76 & 250 & 174 \\
\hline & Elevation (m) & 120.63 & 0.26 & 119.50 & 121 & 1.50 \\
\hline & SOM (\%) & 2.69 & 23.58 & 1.66 & 2.86 & 1.20 \\
\hline & $\mathrm{P}\left(\mathrm{mg} \mathrm{kg}^{-1}\right)$ & 9.88 & 33.81 & 5.68 & 15.00 & 9.32 \\
\hline & $\mathrm{K}^{+}\left(\mathrm{cmol} \mathrm{kg}^{-1}\right)$ & 2.41 & 9.96 & 2.04 & 2.81 & 0.77 \\
\hline & $\mathrm{Mg}^{++}\left(\mathrm{cmol} \mathrm{kg}^{-1}\right)$ & 2.97 & 23.23 & 2.46 & 3.47 & 1.01 \\
\hline & $\mathrm{Ca}^{+2}\left(\mathrm{cmol} \mathrm{kg}^{-1}\right)$ & 6.95 & 19.42 & 5.83 & 8.32 & 2.49 \\
\hline & $\mathrm{Na}^{+2}\left(\mathrm{cmol} \mathrm{kg}^{-1}\right)$ & 0.15 & 58.82 & 0.07 & 0.28 & 0.21 \\
\hline & $\mathrm{pH}$ & 6.72 & 2.15 & 6.06 & 7.00 & 0.94 \\
\hline & CEC $\left(\mathrm{cmol} \mathrm{kg}^{-1}\right)$ & 16.84 & 20.13 & 14.17 & 19.26 & 5.09 \\
\hline & $\mathrm{NO}_{3}-\mathrm{N}\left(\mathrm{mg} \mathrm{kg}^{-1}\right)$ & 48.07 & 12.48 & 38.90 & 61.33 & 22.43 \\
\hline & $\mathrm{SO}_{4}^{-2}-\mathrm{S}\left(\mathrm{mg} \mathrm{kg}^{-1}\right)$ & 9.91 & 11.10 & 4.75 & 14.29 & 9.54 \\
\hline & $\mathrm{Zn}^{+2}\left(\mathrm{mg} \mathrm{kg}^{-1}\right)$ & 0.94 & 21.28 & 0.67 & 1.00 & 0.33 \\
\hline & $\mathrm{Mn}^{+2}\left(\mathrm{mg} \mathrm{kg}^{-1}\right)$ & 47.26 & 19.21 & 34.09 & 63.69 & 29.60 \\
\hline \multirow{20}{*}{$\mathrm{F} 2$} & $\mathrm{Fe}^{+2}\left(\mathrm{mg} \mathrm{kg}^{-1}\right)$ & 122.27 & 10.43 & 99.12 & 149.53 & 50.41 \\
\hline & $\mathrm{Cu}^{+2}\left(\mathrm{mg} \mathrm{kg}^{-1}\right)$ & 1.10 & 10.91 & 0.79 & 1.41 & 0.62 \\
\hline & $\mathrm{EC}_{1: 2.5}\left(\mathrm{dS} \mathrm{m}^{-1}\right)$ & 1.27 & 38.46 & 0.80 & 2.00 & 1.20 \\
\hline & $\mathrm{EC}_{\mathrm{a}}\left(\mathrm{mS} \mathrm{m}^{-1}\right)$ & 104.05 & 53.63 & 45 & 200 & 155 \\
\hline & Elevation (m) & 121.12 & 0.24 & 120.30 & 121.60 & 1.30 \\
\hline & SOM $(\%)$ & 2.91 & 20.27 & 2.31 & 3.65 & 1.34 \\
\hline & $\mathrm{P}\left(\mathrm{mg} \mathrm{kg}^{-1}\right)$ & 15.75 & 68.19 & 7.36 & 32.67 & 25.31 \\
\hline & $\mathrm{K}^{+}\left(\mathrm{cmol} \mathrm{kg}^{-1}\right)$ & 2.24 & 14.23 & 1.71 & 3.37 & 1.66 \\
\hline & $\mathrm{Mg}^{++}\left(\mathrm{cmol} \mathrm{kg}^{-1}\right)$ & 2.74 & 6.57 & 2.57 & 3.01 & 0.44 \\
\hline & $\mathrm{Ca}^{+2}\left(\mathrm{cmol} \mathrm{kg}^{-1}\right)$ & 7.16 & 10.06 & 5.70 & 8.10 & 2.40 \\
\hline & $\mathrm{Na}^{+2}\left(\mathrm{cmol} \mathrm{kg}^{-1}\right)$ & 0.12 & 40.00 & 0.07 & 0.19 & 0.12 \\
\hline & $\mathrm{pH}$ & 6.83 & 3.81 & 6.14 & 7.15 & 1.01 \\
\hline & $\mathrm{CEC}\left(\mathrm{cmol} \mathrm{kg}^{-1}\right)$ & 16.19 & 17.91 & 14.95 & 17.18 & 2.23 \\
\hline & $\mathrm{NO}_{3}^{-}-\mathrm{N}\left(\mathrm{mg} \mathrm{kg}^{-1}\right)$ & 66.62 & 10.51 & 52.89 & 83.99 & 31.10 \\
\hline & $\mathrm{SO}_{4}^{-2}-\mathrm{S}\left(\mathrm{mg} \mathrm{kg}^{-1}\right)$ & 15.37 & 1.69 & 15.00 & 15.88 & 0.88 \\
\hline & $\mathrm{Zn}^{+2}\left(\mathrm{mg} \mathrm{kg}^{-1}\right)$ & 1.54 & 38.96 & 0.77 & 2.54 & 1.77 \\
\hline & $\mathrm{Mn}^{+2}\left(\mathrm{mg} \mathrm{kg}^{-1}\right)$ & 42.78 & 38.38 & 20.00 & 70.21 & 50.21 \\
\hline & $\mathrm{Fe}^{+2}\left(\mathrm{mg} \mathrm{kg}^{-1}\right)$ & 108.42 & 7.68 & 95.00 & 122.06 & 27.06 \\
\hline & $\mathrm{Cu}^{+2}\left(\mathrm{mg} \mathrm{kg}^{-1}\right)$ & 1.03 & 11.65 & 0.68 & 1.24 & 0.56 \\
\hline & $\mathrm{EC}_{1: 2.5}\left(\mathrm{dS} \mathrm{m} \mathrm{m}^{-1}\right)$ & 0.96 & 33.33 & 0.70 & 1.75 & 1.05 \\
\hline
\end{tabular}

SOM: soil organic matter, $\mathrm{CEC}$ : cation exchange capacity, $\mathrm{EC}_{1: 2.5}$ : laboratory-measured electrical conductivity. conduct electricity more easily than sandy soils (Rhoades et al., 1989).

Standard criteria suggested by Wilding et al. (1994) were used to characterize the magnitude of variability of soil properties and nutrient levels; with CV from $0 \%$ to $15 \%, 15 \%$ to $35 \%$, and $35 \%$ to $100 \%$ characterizing low, medium, and high variability, respectively. Soil SOM for both fields ranged from $1.20 \%$ to $1.34 \%$ with whole field CV ranging from $23.58 \%$ to $20.57 \%$, which showed medium variability (Table 1 ). Soil CEC, $\mathrm{Ca}^{+2}, \mathrm{Mg}^{+2}, \mathrm{Zn}^{+2}$, and $\mathrm{Mn}^{+2}$ contents had medium variability among fields, while the concentration of $\mathrm{K}^{+}, \mathrm{NO}_{3}^{-}-\mathrm{N}, \mathrm{SO}_{4}^{-2}-\mathrm{S}, \mathrm{Fe}^{+2}$ and $\mathrm{Cu}^{+2}$ and $\mathrm{pH}$ had low variability. However, $\mathrm{P}, \mathrm{Na}^{+}$and $\mathrm{EC}_{1: 2.5}$ showed higher variability (Table 1 ). The higher mean of $\mathrm{Na}^{+}$content and $\mathrm{EC}_{1: 2.5}$ in $\mathrm{F} 1$ was probably due to the predominance of Aromos and Medanitos series, while the Canals series prevailed in F2. CVs for soil properties indicated high spatial variability and suggested the convenience of defining different management zones. High spatial variability in soil properties is the consequence of the interaction of (i) soil formation processes, (ii) meteorological processes, and (iii) anthropogenic influences. Soil formation processes are the result of complex interactions between biological, physical, and chemical mechanisms acting on a parent material over time and influenced by topography (Moral et al., 2010).

\subsection{Relationships among $E C_{a}$ with soil properties and nutrient concentrations}

Table 2 shows all PCs with an eigenvalue greater than 1, which were selected because they explained a significant amount of the variance present in the soil properties and nutrient levels at each field. In both cases, PCs had a cumulative variance of more than $80 \%$. In both fields, the first PC (PC1) explained $>60 \%$ of the total variance and was strongly influenced by all soil properties and $\mathrm{Zn}^{+2}, \mathrm{Ca}^{+2}, \mathrm{Mg}^{+2}, \mathrm{Mn}^{+2}, \mathrm{Na}^{+}, \mathrm{Fe}^{+2}$ and $\mathrm{Cu}^{+2}$. The second PC (PC2) and third $\mathrm{PC}$ (PC3) showed a more intense relationship with $\mathrm{P}, \mathrm{K}^{+}$ and $\mathrm{NO}_{3}^{-}-\mathrm{N}, \mathrm{SO}_{4}^{-2}-\mathrm{S}$, respectively.

For both fields, the PC-stepwise regression analysis only retained PC1 (Table 3). $\mathrm{EC}_{1: 2.5}, \mathrm{pH}, \mathrm{CEC}, \mathrm{Ca}^{+2}, \mathrm{Mg}^{+2}$ and $\mathrm{Na}^{+}$contents had the highest positive loading factors and were positively related to $\mathrm{EC}_{\mathrm{a}}$, which was associated with lower areas of the fields. In contrast, $\mathrm{SOM}, \mathrm{Zn}^{+2}, \mathrm{Mn}^{+2}, \mathrm{Fe}^{+2}, \mathrm{Cu}^{+2}$ had the highest negative loading factors and were negatively related to $\mathrm{EC}_{\mathrm{a}}$.

The correlation between elevation and $\mathrm{EC}_{\mathrm{a}}$ was significant and negative (Table 4). The higher $\mathrm{EC}_{\mathrm{a}}$ values are observed in lower areas (formed mainly by Aromos and Medanitos series) (Figs. 1 and 3), where salts, $\mathrm{pH}, \mathrm{Na}^{+}$and CEC levels were higher than in higher areas (formed mainly by the Canals series) (Table 5 and Fig. 4). Surface topography plays a significant role in influencing spatial EC $\mathrm{C}_{\mathrm{a}}$ variation (Kravchenko and Bullock, 2002). Slope and aspect will determine the level and location of run-off and infiltration, which will influence the variation in water content and salinity. Areas where the slope is steep tend to have lower water content than areas where a depression occurs (Marques da Silva and Silva, 2008). The influence of surface topography on salinity distribution coincides with the influence of surface topography on water-flow gradients, which results in salt transport (Corwin and Lesch, 2005).

Three variables $\left(\mathrm{EC}_{1: 2.5}, \mathrm{pH}\right.$ and $\left.\mathrm{Na}^{+}\right)$were highly correlated with $\mathrm{EC}_{\mathrm{a}}$ and presented values $r>0.67$ for both fields. This high correlation is expected because it reflects the influence of salts on the $\mathrm{EC}_{\mathrm{a}}$ reading and because these properties are highly correlated (Kaffka et al., 2005). Salts and $\mathrm{Na}^{+}$concentrations increased soil solution conductivity (Rhoades et al., 1989) and is consistent with findings in previous studies (Kaffka et al., 2005).

The $\mathrm{EC}_{\mathrm{a}}$ showed a positive correlation with $\mathrm{CEC}, \mathrm{Ca}^{+2}$ and $\mathrm{Mg}^{+2}$ (Table 4). This indicates that changes in $\mathrm{Ca}^{+2}$ and $\mathrm{Mg}^{+2}$ 
Table 2

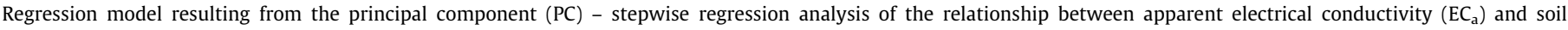
properties-nutrients.

\begin{tabular}{|c|c|c|c|c|c|c|c|c|c|c|c|c|c|c|c|c|c|c|}
\hline \multirow[t]{2}{*}{ Fields } & \multirow[t]{2}{*}{ Key PCs } & \multirow[t]{2}{*}{ Eigenvalue } & \multirow[t]{2}{*}{ Cumulative $\sigma^{2}$} & \multicolumn{15}{|c|}{ Parameter } \\
\hline & & & & SOM & $\mathrm{P}$ & $\mathrm{K}^{+}$ & $\mathrm{Mg}^{+2}$ & $\mathrm{Ca}^{+2}$ & $\mathrm{Na}^{+2}$ & $\mathrm{pH}$ & CEC & $\mathrm{NO}_{3}-\mathrm{N}$ & $\mathrm{SO}_{4}^{-2}-\mathrm{S}$ & $\mathrm{Zn}^{+2}$ & $\mathrm{Mn}^{+2}$ & $\mathrm{Fe}^{+2}$ & $\mathrm{Cu}^{+2}$ & $\mathrm{EC}_{1: 2.5}$ \\
\hline \multirow{3}{*}{ F1 } & CP 1 & 8.7 & 0.61 & -0.4 & -0.19 & 0.26 & 0.44 & 0.42 & 0.46 & 0.46 & 0.45 & 0.15 & -0.26 & -0.41 & -0.44 & -0.41 & -0.43 & 0.47 \\
\hline & CP 2 & 2.1 & 0.73 & 0.14 & 0.54 & 0.53 & 0.15 & 0.29 & -0.01 & -0.01 & 0.11 & 0.13 & 0.44 & -0.14 & 0.03 & -0.01 & 0.15 & -0.19 \\
\hline & CP 3 & 1.4 & 0.82 & -0.03 & -0.11 & 0.23 & -0.02 & -0.12 & 0.09 & 0.12 & 0.1 & 0.78 & -0.11 & 0.32 & -0.01 & 0.37 & -0.05 & 0.15 \\
\hline \multirow{3}{*}{ F2 } & CP 1 & 9.57 & 0.64 & -0.43 & 0.18 & 0.21 & 0.45 & 0.44 & 0.42 & 0.45 & 0.41 & 0.29 & -0.33 & -0.45 & -0.45 & -0.44 & -0.44 & 0.46 \\
\hline & CP 2 & 2.57 & 0.81 & -0.14 & 0.61 & 0.57 & -0.02 & 0.15 & -0.09 & 0.06 & 0.15 & -0.02 & 0.45 & 0.06 & 0.19 & 0.18 & -0.16 & -0.02 \\
\hline & CP 3 & 1.59 & 0.92 & -0.26 & -0.13 & -0.27 & 0.17 & 0.04 & -0.21 & -0.25 & 0.18 & 0.53 & 0.38 & -0.1 & 0.1 & 0.05 & 0.22 & -0.21 \\
\hline
\end{tabular}

SOM: soil organic matter, $\mathrm{CEC}$ : cation exchange capacity, $\mathrm{EC}_{1: 2.5}$ : laboratory-measured electrical conductivity. Bold values indicate significant loading factors $>0.4$.

Table 3

Key principal components (PCs) (eigenvalues > 1.0), cumulative variance and loading factors for each soil property and nutrient.

\begin{tabular}{|c|c|c|c|c|c|c|}
\hline \multirow[t]{2}{*}{ Fields } & \multirow[t]{2}{*}{$\begin{array}{l}\text { Regression } \\
\text { model }\end{array}$} & \multirow[t]{2}{*}{$R^{2}$} & \multirow[t]{2}{*}{ RMS } & \multirow[t]{2}{*}{$p$} & \multicolumn{2}{|c|}{$\begin{array}{l}\text { Key latent variables } \\
\text { (loading factors }>0.4 \text { ) } \\
\text { (listed in order of } \\
\text { importance) }\end{array}$} \\
\hline & & & & & $\begin{array}{l}\text { Soil } \\
\text { properties }\end{array}$ & Nutrients \\
\hline F1 & $\begin{array}{l}139.25+18.20^{*} \\
\text { PC1 }\end{array}$ & 0.94 & 0.61 & 0.0001 & $\begin{array}{l}\mathrm{pH}, \\
\mathrm{EC}_{1: 2.5}, \\
\mathrm{CEC}, \mathrm{SOM}\end{array}$ & $\begin{array}{l}\mathrm{Na}^{+2}, \mathrm{Mg}^{+2}, \\
\mathrm{Mn}^{+2}, \mathrm{Cu}^{+2}, \\
\mathrm{Ca}^{+2}, \mathrm{Zn}^{+2}, \\
\mathrm{Fe}^{+2}\end{array}$ \\
\hline $\mathrm{F} 2$ & $\begin{array}{l}101.76+17.37^{*} \\
\text { PC1 }\end{array}$ & 0.91 & 0.64 & 0.0071 & $\begin{array}{l}\mathrm{pH}, \\
\mathrm{EC}_{1: 2.5} \\
\text { SOM, CEC }\end{array}$ & $\begin{array}{l}\mathrm{Mg}^{+2}, \mathrm{Zn}^{+2}, \\
\mathrm{Mn}^{+2}, \mathrm{Ca}^{+2}, \\
\mathrm{Fe}^{+2}, \mathrm{Cu}^{+2}, \\
\mathrm{Na}^{+2}\end{array}$ \\
\hline
\end{tabular}

SOM: soil organic matter, $\mathrm{CEC}$ : cation exchange capacity, $\mathrm{EC}_{1: 2.5}$ : laboratory-measured electrical conductivity, RMS: root mean square.

concentrations associated with changes in the CEC across the fields were influencing $\mathrm{EC}_{\mathrm{a}}$. Increases in the $\mathrm{CEC}$ contributed to the raised concentration of $\mathrm{Ca}^{+2}$ and $\mathrm{Mg}^{+2}$ in the soil solution and to increasing the electrical conductivity of soil particles, which increased the EC $_{\mathrm{a}}$ (Shainberg et al., 1980). The CEC might be linked to clay content, because the highest values were found in the sampling points on the Aromos series (loam). In contrast, the lowest values of CEC (and hence $\mathrm{Ca}^{+2}, \mathrm{Mg}^{+2}$ ) were associated with the Canals series (sandy loam). Heiniger et al. (2003) reported that sand was negatively related to $\mathrm{Ca}^{+2}$ and $\mathrm{Mg}^{+2}$ levels, while silt and clay were positively related. It is clear that the $\mathrm{CEC}, \mathrm{Ca}^{+2}$ and $\mathrm{Mg}^{+2}$ concentrations affected the $\mathrm{EC}_{\mathrm{a}}$ measurements, due to the influence on the electrical conductivity of the soil particles. However, the common assumption is that in soils with salinity problems, salts have a greater influence on the $\mathrm{EC}_{\mathrm{a}}$ variability (Rhoades et al., 1989), either by affecting the electrical conductivity of the soil solution associated with discontinuous pores or by the electrical conductivity of the mobile soil solution associated with large, continuous pores (Shainberg et al., 1980; Malicki and Walczak, 1999).

Moreover, the $\mathrm{EC}_{\mathrm{a}}$ showed a negative correlation with SOM, and between SOM and $\mathrm{EC}_{1: 2.5}$ (Table 4). High concentrations of salt in soils influence soil organic matter (SOM) content. Salinity has been found to have a negative influence on the activity of soil microbial biomass and biochemical processes essential for the maintenance of soil organic matter (Tripathi et al., 2006). In agricultural fields without salts present, high $\mathrm{EC}_{\mathrm{a}}$ was associated with the highest values of SOM (Heiniger et al., 2003; Peralta et al., 2013). Also, the $\mathrm{EC}_{\mathrm{a}}$ showed a negative correlation with $\mathrm{Zn}^{+2}, \mathrm{Mn}^{+2}, \mathrm{Fe}^{+2}$ and $\mathrm{Cu}^{+2}$ concentrations (Table 4 ).

Conversely, PC2 and PC3 showed a more intense relationship with $\mathrm{P}, \mathrm{K}^{+}, \mathrm{NO}_{3}-\mathrm{N}$ and $\mathrm{SO}_{4}^{-2}-\mathrm{S}$ ), (Table 2). PC2 and PC3 were not retained in the PC-regression model in both fields (Table 3). These variables showed no significant correlation with the $\mathrm{EC}_{\mathrm{a}}$ (Table 4) because the variation was very low (CVs $<15 \%$, Table 1 ), except for $\mathrm{P}(\mathrm{CVs}$ were $>30 \%)$. The low association between $\mathrm{EC}_{\mathrm{a}}$ and $\mathrm{P}$ is probably due to the fact that equivalent conductances of common inorganic $\mathrm{P}$ ions in soils (e.g. $\mathrm{H}_{2} \mathrm{PO}_{4}^{-}$and $\mathrm{HPO}_{4}^{-2}$ ) are generally lower than ionic species (e.g. $\mathrm{Ca}^{+2}$ and $\mathrm{Mg}^{+2}$ ) (Motavalli et al., 2013). Furthermore, Jung et al. (2005) mentioned that the low association between $\mathrm{EC}_{\mathrm{a}}$ and $\mathrm{P}$ is attributable to the influence of fertilization form (band application) and tillage system (direct drilling, without soil removal). The available $\mathrm{N}$ and $\mathrm{S}$ levels were not related to the variability of the $\mathrm{EC}_{\mathrm{a}}$, this may be explained by variation and low concentrations of these anions, without influence on the electrical conductivity of the mobile soil solution. Corwin et al. (2006) found a very strong correlation between $\mathrm{EC}_{\mathrm{a}}$ with $\mathrm{NO}_{3}^{-}-\mathrm{N}$ and $\mathrm{SO}_{4}^{-2}-\mathrm{S}$ ), contents working in fields with higher concentrations and variations.

Identification of regression models that were able to account for a large portion (50\%) of the variability in soil $\mathrm{EC}_{\mathrm{a}}$ would indicate situations where $\mathrm{EC}_{\mathrm{a}}$ could be used successfully to measure soil properties and nutrient levels (Heiniger et al., 2003). As can be seen, the $\mathrm{EC}_{\mathrm{a}}$ was strongly linked to soil properties, mainly $\mathrm{EC}_{1: 2.5}$ and $\mathrm{pH}$ (higher loading factors). It was also correlated with some exchange cations such as $\mathrm{Zn}^{+2}, \mathrm{Ca}^{+2}, \mathrm{Mg}^{+2}, \mathrm{Mn}^{+2}, \mathrm{Na}^{+}, \mathrm{Fe}^{+2}$ and $\mathrm{Cu}^{+2}$; there were no correlations with $\mathrm{K}^{+}, \mathrm{P}, \mathrm{NO}_{3}^{-}-\mathrm{N}$ and $\mathrm{SO}_{4}^{-2}-\mathrm{S}$ ), indicating that $\mathrm{EC}_{\mathrm{a}}$ measurements in these fields were driven primarily by salinity.

\subsection{Delineation of homogeneous management zones}

While the PCA revealed which soil properties and nutrients explained the major total variance, and the PC-stepwise regression determined which soil properties and nutrients were more associated with $\mathrm{EC}_{\mathrm{a}}$, neither of these two techniques can determine significant differences among $\mathrm{EC}_{\mathrm{a}}$ classes. Therefore, to assess whether $\mathrm{EC}_{\mathrm{a}}$ can be used to determine HMZ, a mixed ANOVA model was fitted (Table 5).

The soil properties $\left(\mathrm{EC}_{1: 2.5}, \mathrm{pH}, \mathrm{CEC}\right.$ and $\mathrm{SOM}$ ) had the greater significant differences among $\mathrm{EC}_{\mathrm{a}}$ classes in each field (Table 5), which is consistent with the results of the PCA. These soil properties were considered key latent variables (loading factors $>0.4$ ) because they substantially influence the relationship between PC1 and the $\mathrm{EC}_{\mathrm{a}}$ (Table 3). The $\mathrm{EC}_{1: 2.5}$ and $\mathrm{pH}$ exhibited significant differences between two $\mathrm{EC}_{\mathrm{a}}$ classes (Table 5). The delimitation of areas with different values of $\mathrm{EC}_{1: 2.5}$ and $\mathrm{pH}$ is very important for SSM because soil salinity refers to the presence of major dissolved inorganic solutes in the soil aqueous phase. These consist of soluble and readily dissolvable salts including charged species, non-ionic solutes, and ions that combine to form ion pairs (Corwin and Lesch, 2005). Salinity limits water uptake by plants because it reduces the osmotic potential, making it more difficult for the plant 
Table 4

Correlations between apparent electrical conductivity $\left(\mathrm{EC}_{\mathrm{a}}\right)$, elevation, soil properties and nutrient concentrations in each field.

\begin{tabular}{|c|c|c|c|c|c|c|c|c|c|c|c|c|c|c|c|c|c|c|}
\hline Fields & Variables & $\mathrm{EC}_{\mathrm{a}}$ & Elevation & SOM & $P$ & $\mathrm{~K}^{+}$ & $\mathrm{Mg}^{++}$ & $\mathrm{Ca}^{+2}$ & $\mathrm{Na}^{+2}$ & $\mathrm{pH}$ & CEC & $\mathrm{NO}_{3}^{-}-\mathrm{N}$ & $\mathrm{SO}_{4}^{-2}-\mathrm{S}$ & $\mathrm{Zn}^{+2}$ & $\mathrm{Mn}^{+2}$ & $\mathrm{Fe}^{+2}$ & $\mathrm{Cu}^{+2}$ & $\mathrm{EC}_{1: 2.5}$ \\
\hline \multirow{15}{*}{ F1 } & $\mathrm{EC}_{\mathrm{a}}$ & 1 & $-^{* * * *}$ & - $^{* * *}$ & ns & ns & $-^{* * *}$ & - $^{* * * * *}$ & - $^{* * * * *}$ & - $^{* * * *}$ & - $^{* * * *}$ & ns & ns & - $^{* * *}$ & - $^{* * * *}$ & $-^{* * * *}$ & - $^{* * * *}$ & - $^{* * * *}$ \\
\hline & Elevation & -0.91 & 1 & - $^{* *}$ & ns & ns & - $^{* * * *}$ & $-^{* * * *}$ & - $^{* * * *}$ & $-^{* * * *}$ & - $^{* * * *}$ & $\mathrm{~ns}$ & ns & - $^{* *}$ & - $^{* * * *}$ & $-^{*}$ & $-^{*}$ & - $^{* * * *}$ \\
\hline & SOM & -0.72 & 0.71 & 1 & ns & ns & - $^{*}$ & $-^{*}$ & - $^{*}$ & $-^{*}$ & ns & ns & ns & ns & - $^{* * * *}$ & ns & $-^{* * *}$ & $-^{* *}$ \\
\hline & $P$ & -0.11 & 0.23 & 0.3 & 1 & ns & ns & ns & ns & ns & ns & ns & ns & ns & ns & ns & ns & ns \\
\hline & $\mathrm{K}^{+}$ & 0.34 & -0.44 & -0.14 & 0.45 & 1 & ns & $-^{* * *}$ & ns & ns & ns & ns & ns & $-{ }^{*}$ & ns & ns & ns & ns \\
\hline & $\mathrm{Mg}^{++}$ & 0.76 & -0.89 & -0.66 & -0.14 & 0.42 & 1 & - $^{* * * *}$ & $-{ }^{* * * *}$ & $-* *$ & $-* * *$ & ns & ns & - $^{* * * *}$ & $-^{* * * *}$ & $-{ }^{* *}$ & - & - \\
\hline & $\mathrm{Ca}^{+2}$ & 0.84 & -0.84 & -0.57 & 0.11 & 0.59 & 0.9 & 1 & $-^{* *}$ & - $^{* *}$ & - $^{* * *}$ & ns & ns & $-^{* *}$ & - $^{* * * *}$ & $-^{*}$ & $-^{*}$ & $-^{*}$ \\
\hline & $\mathrm{Na}^{+2}$ & 0.67 & -0.77 & -0.64 & -0.04 & 0.28 & 0.78 & 0.71 & 1 & $-{ }^{*}$ & - $^{* * * *}$ & ns & ns & $-^{* *}$ & - $^{* * * *}$ & - & $-^{* * * *}$ & $-{ }^{*}$ \\
\hline & $\mathrm{pH}$ & 0.93 & -0.76 & -0.64 & 0.00 & 0.36 & 0.7 & 0.7 & 0.67 & 1 & - $^{* * * *}$ & ns & ns & $-^{*}$ & $-^{* *}$ & - $^{* *}$ & $-^{* * * *}$ & - $^{* * * *}$ \\
\hline & CEC & 0.89 & -0.9 & -0.25 & -0.13 & 0.46 & 0.92 & 0.89 & 0.59 & 0.55 & 1 & ns & ns & $-{ }^{*}$ & $-^{* * * *}$ & $-^{*}$ & $-^{* *}$ & - $^{* * * *}$ \\
\hline & $\mathrm{NO}_{3}^{-}-\mathrm{N}$ & -0.05 & 0.1 & 0.05 & 0.03 & 0.29 & 0.08 & -0.06 & 0.18 & 0.14 & 0.13 & 1 & ns & ns & ns & ns & ns & ns \\
\hline & $\mathrm{SO}_{4}^{-2}-\mathrm{S}$ & -0.58 & 0.55 & 0.41 & 0.54 & 0.09 & -0.29 & -0.15 & -0.57 & -0.59 & -0.4 & 0.04 & 1 & ns & ns & ns & $-{ }^{*}$ & $-{ }^{* * *}$ \\
\hline & $\mathrm{Zn}^{+2}$ & -0.80 & 0.72 & 0.43 & -0.01 & -0.39 & -0.76 & -0.78 & -0.71 & -0.67 & -0.66 & 0.24 & 0.38 & 1 & - $^{* * *}$ & $-^{* * * *}$ & $-{ }^{*}$ & $\mathrm{~ns}$ \\
\hline & $\mathrm{Mn}^{+2}$ & -0.83 & 0.75 & 0.77 & 0.34 & -0.2 & -0.87 & -0.75 & -0.76 & -0.69 & -0.83 & -0.1 & 0.35 & 0.71 & 1 & - $^{* *}$ & $-{ }^{* *}$ & $-{ }^{*}$ \\
\hline & $\mathrm{Fe}^{+2}$ & -0.63 & 0.67 & 0.52 & -0.07 & -0.05 & -0.71 & -0.64 & -0.81 & -0.72 & -0.61 & 0.28 & 0.37 & 0.81 & 0.68 & 1 & $-^{* *}$ & $-^{*}$ \\
\hline \multirow{19}{*}{ F2 } & $\mathrm{Cu}^{+2}$ & -0.77 & 0.64 & 0.72 & 0.11 & -0.13 & -0.57 & -0.56 & -0.88 & -0.89 & -0.69 & -0.05 & 0.64 & 0.6 & 0.72 & 0.72 & 1 & - $^{* * * *}$ \\
\hline & $\mathrm{EC}_{1: 2.5}$ & 0.90 & -0.8 & -0.73 & -0.24 & 0.16 & 0.68 & 0.59 & 0.61 & 0.92 & 0.76 & 0.1 & -0.77 & -0.53 & -0.66 & -0.66 & -0.88 & 1 \\
\hline & $\mathrm{EC}_{\mathrm{a}}$ & 1 & $-{ }^{*}$ & - $^{*}$ & ns & ns & $-^{* * * *}$ & $-^{* * *}$ & $-^{* * * *}$ & $-^{* * *}$ & $-^{* * *}$ & ns & ns & $-^{* * *}$ & $-^{* * *}$ & $-^{* *}$ & $-^{* * * *}$ & $-^{* * * *}$ \\
\hline & Elevation & -0.70 & 1 & ns & ns & ns & $-^{*}$ & ns & $-^{*}$ & ns & ns & ns & ns & $-^{* *}$ & - $^{*}$ & ns & ns & - $^{* *}$ \\
\hline & SOM & -0.71 & 0.52 & 1 & ns & ns & $-{ }^{* * *}$ & $-{ }^{*}$ & - $^{*}$ & - & ns & ns & ns & $-^{* *}$ & $-{ }^{*}$ & $-{ }^{*}$ & $-* *$ & $-{ }^{*}$ \\
\hline & $\mathrm{P}$ & 0.03 & 0.08 & -0.25 & 1 & $-^{* * * *}$ & ns & ns & ns & ns & ns & ns & ns & ns & ns & ns & ns & ns \\
\hline & $\mathrm{K}^{+}$ & 0.15 & 0.01 & -0.26 & 0.98 & 1 & ns & ns & ns & ns & ns & ns & ns & ns & ns & ns & ns & ns \\
\hline & $\mathrm{Mg}^{++}$ & 0.67 & -0.73 & -0.88 & 0.01 & 0.07 & 1 & $-{ }^{* *}$ & $-^{* * *}$ & $-^{* * * *}$ & - $^{* *}$ & ns & ns & $-{ }^{* * * *}$ & - $^{* * * *}$ & $-{ }^{* *}$ & $-{ }^{* * *}$ & $-^{* * *}$ \\
\hline & $\mathrm{Ca}^{+2}$ & 0.72 & -0.57 & -0.76 & 0.28 & 0.34 & 0.91 & 1 & $-{ }^{* * *}$ & - $^{* * * *}$ & $-{ }^{* * *}$ & ns & ns & $-^{* *}$ & - $^{*}$ & $-^{*}$ & $-^{*}$ & $-{ }^{*}$ \\
\hline & $\mathrm{Na}^{+2}$ & 0.70 & -0.64 & -0.70 & 0.19 & 0.33 & 0.83 & 0.83 & 1 & $-^{* * *}$ & $-{ }^{* *}$ & ns & ns & $-^{* *}$ & $-^{* * * *}$ & $-{ }^{*}$ & $-^{* * * *}$ & $-{ }^{*}$ \\
\hline & $\mathrm{pH}$ & 0.95 & -0.56 & -0.72 & 0.22 & 0.34 & 0.84 & 0.87 & 0.66 & 1 & $-^{*}$ & ns & ns & $-^{* *}$ & - $^{* * * *}$ & $-^{* *}$ & $-^{* * *}$ & $-^{* * *}$ \\
\hline & CEC & 0.78 & -0.47 & -0.29 & -0.12 & -0.05 & 0.79 & 0.78 & 0.52 & 0.66 & 1 & ns & ns & $-^{* * *}$ & $-^{* * *}$ & $-{ }^{*}$ & $-{ }^{*}$ & $-^{* * *}$ \\
\hline & $\mathrm{NO}_{3}^{-}-\mathrm{N}$ & -0.38 & -0.42 & -0.89 & -0.04 & -0.08 & 0.81 & 0.63 & 0.42 & 0.44 & 0.46 & 1 & ns & ns & ns & $-{ }^{*}$ & ns & ns \\
\hline & $\mathrm{SO}_{4}^{-2}-\mathrm{S}$ & -0.32 & 0.42 & 0.24 & 0.42 & 0.22 & -0.48 & -0.35 & -0.62 & -0.59 & -0.49 & -0.14 & 1 & ns & $-^{* * *}$ & $-{ }^{* *}$ & ns & $-{ }^{*}$ \\
\hline & $\mathrm{Zn}^{+2}$ & -0.81 & 0.77 & 0.77 & 0.07 & 0.02 & -0.92 & -0.81 & -0.80 & -0.83 & -0.88 & -0.65 & 0.41 & 1 & - $^{* * * *}$ & - $^{* *}$ & - $^{*}$ & $-^{* * * *}$ \\
\hline & $\mathrm{Mn}^{+2}$ & -0.82 & 0.69 & 0.73 & 0.19 & 0.06 & -0.87 & -0.72 & -0.85 & -0.86 & -0.78 & -0.59 & 0.79 & 0.85 & 1 & $-^{* * *}$ & $-^{* *}$ & $-^{* * * *}$ \\
\hline & $\mathrm{Fe}^{+2}$ & -0.73 & 0.56 & 0.76 & 0.18 & 0.05 & -0.83 & -0.67 & -0.77 & -0.81 & -0.70 & -0.65 & 0.77 & 0.77 & 0.97 & 1 & - $^{* *}$ & - $^{*}$ \\
\hline & $\mathrm{Cu}^{+2}$ & -0.67 & 0.54 & 0.80 & -0.38 & -0.50 & -0.77 & -0.77 & -0.91 & -0.92 & -0.65 & -0.48 & 0.52 & 0.72 & 0.82 & 0.81 & 1 & $-^{* * * *}$ \\
\hline & $\mathrm{EC}_{1: 2.5}$ & 0.96 & -0.81 & -0.65 & 0.06 & 0.18 & 0.82 & 0.76 & 0.55 & 0.90 & 0.81 & 0.39 & -0.61 & -0.87 & -0.87 & -0.74 & -0.84 & 1 \\
\hline
\end{tabular}

SOM: soil organic matter, CEC: cation exchange capacity, $\mathrm{EC}_{1: 2.5}$ : laboratory-measured electrical conductivity.

ns, not significant.

* Significant at the $\alpha=0.05$ error level.

** Significant at the $\alpha=0.01$ error level.

**** Significant at the $\alpha=0.001$ error level.

to extract water. Salinity may also cause specific ion toxicity or upset the nutritional balance of plants, reducing crop yields (Corwin and Lesch, 2005). Also, pH controls the nutrient availability for plants and soil microbial activity (Serrano et al., 2010). The SOM and CEC exhibited significant differences among two $\mathrm{EC}_{\mathrm{a}}$ classes, but with an inverse pattern (Table 5). Bearing in mind that CEC and SOM are relatively static over time (Shaner et al., 2008), and that they affect crop growth and development (Groenigen et al., 2000), it would be useful and necessary to classify fields into homogeneous zones. The classes of high $\mathrm{EC}_{\mathrm{a}}$ showed lower values of SOM. In a previous study published by Gambaudo et al. (2008), it was observed that in medium-low zones of $\mathrm{EC}_{\mathrm{a}}$, the SOM increased. Also, the nutrients with high loading factors $\left(\mathrm{Zn}^{+2}, \mathrm{Ca}^{+2}\right.$, $\mathrm{Mg}^{+2}, \mathrm{Mn}^{+2}, \mathrm{Na}^{+}, \mathrm{Fe}^{+2}$ and $\mathrm{Cu}^{+2}$ ) showed greater significant differences among the $\mathrm{EC}_{\mathrm{a}}$ classes in each field. The micronutrient concentrations $\left(\mathrm{Zn}^{+2}, \mathrm{Mn}^{+2}, \mathrm{Fe}^{+2}\right.$ and $\left.\mathrm{Cu}^{+2}\right)$ exhibited significant differences among the two $\mathrm{EC}_{\mathrm{a}}$ classes. In most cases, they showed no difference between the medium-high classes, except $\mathrm{Cu}^{+2}$ in F1 (Table 5). The high micronutrient concentrations in the low $\mathrm{EC}_{\mathrm{a}}$ class were attributed to increasing soil acidification and relatively high SOM contents (Shuman, 1991; Shi et al., 2008; Eyherabide et al., 2012). The concentrations of $\mathrm{Ca}^{+2}, \mathrm{Mg}^{+2}$ showed differences among two classes, while $\mathrm{K}^{+}$showed no significant differences among $\mathrm{EC}_{\mathrm{a}}$ classes (Table 5), possibly because of the low CV exhibited in F1 and F2 (9.96\% and $14.23 \%$, respectively) (Table 1$)$. The $\mathrm{Na}^{+2}$ concentrations showed differences among two $\mathrm{EC}_{\mathrm{a}}$ classes (Table 5). Bosch Mayol et al. (2012), working in soils with a higher
$\mathrm{Na}^{+2}$ content, found differences in three zones, concluding that the $\mathrm{Na}^{+2}$ spatial variability significantly affects $\mathrm{EC}_{\mathrm{a}}$.

However, the nutrients with low loading factors $\left(\mathrm{K}^{+}, \mathrm{P}, \mathrm{NO}_{3}^{-}-\mathrm{N}\right.$ and $\mathrm{SO}_{4}^{-2}-\mathrm{S}$ ), did not show significant differences among $\mathrm{EC}_{\mathrm{a}}$ classes (Table 5). The $\mathrm{NO}_{3}^{-}-\mathrm{N}$ and $\mathrm{SO}_{4}^{-2}-\mathrm{S}$ ), concentrations had low $\mathrm{CVs}$, indicating that these variables showed little variation within the fields. Also, transformations in soil are controlled by soil water content, biological activity, cropping, composition and quantity of organic matter. These soil characteristics have an impact on the discordant processes of immobilization and leaching (losses) or mineralization (gains) that define $\mathrm{NO}_{3}^{-}-\mathrm{N}$ and $\mathrm{SO}_{4}^{-2}-\mathrm{S}$ ), levels in soil (Eriksen, 1997). While P showed a high CV, it was not a variable that significantly affected the $\mathrm{EC}_{\mathrm{a}}$.

Geo-referenced $\mathrm{EC}_{\mathrm{a}}$ measurements successfully delimited two homogeneous soil zones associated with spatial distribution of soil properties, such as salt concentration $\left(\mathrm{EC}_{1: 2.5}\right), \mathrm{pH}, \mathrm{CEC}$ and SOM content. Two homogeneous soil zones were also delimited by micronutrients $\left(\mathrm{Zn}^{+2}, \mathrm{Mn}^{+2}, \mathrm{Fe}^{+2}\right.$ and $\left.\mathrm{Cu}^{+2}\right)$ strongly associated with soil pH and SOM (Table 4); and two zones by $\mathrm{Na}^{+}, \mathrm{Ca}^{+2}, \mathrm{Mg}^{+2}$, which showed high correlations with CEC. However, the $\mathrm{K}^{+}, \mathrm{P}, \mathrm{NO}_{3}^{-}-\mathrm{N}$ and $\mathrm{SO}_{4}^{-2}-\mathrm{S}$ ), content had few differences on average in the different $\mathrm{EC}_{\mathrm{a}}$ zones, so it would not be advisable to make management zones based on these three nutrients. Soil properties such as $\mathrm{pH}$, SOM and CEC showed high correlations with nutrient levels and, as they are relatively static over time, a model that included these measurements along with $\mathrm{EC}_{\mathrm{a}}$ could be developed to predict soil nutrient content. Because $\mathrm{EC}_{\mathrm{a}}$ is able to measure these soil properties 
Table 5

Soil properties and nutrient-concentrations means within three zones (classes) of apparent electrical conductivity $\left(\mathrm{EC}_{\mathrm{a}}\right.$ ) in each field.

\begin{tabular}{|c|c|c|c|c|c|c|c|c|c|c|c|c|c|c|c|c|c|}
\hline Fields & $\begin{array}{l}\mathrm{EC}_{\mathrm{a}} \\
\text { Zones }\end{array}$ & $\mathrm{EL}^{\mathrm{a}}$ & $\begin{array}{l}\text { SOM } \\
(\%)\end{array}$ & $\begin{array}{l}\mathrm{P} \\
(\mathrm{mg} \\
\left.\mathrm{kg}^{-1}\right)\end{array}$ & $\begin{array}{l}\mathrm{K}^{+} \\
(\mathrm{cmol} \\
\left.\mathrm{kg}^{-1}\right)\end{array}$ & $\begin{array}{l}\mathrm{Mg}^{+2} \\
\left(\mathrm{cmol}^{-1}\right. \\
\left.\mathrm{kg}^{-1}\right)\end{array}$ & $\begin{array}{l}\mathrm{Ca}^{+2} \\
(\mathrm{cmol} \\
\left.\mathrm{kg}^{-1}\right)\end{array}$ & $\begin{array}{l}\mathrm{Na}^{+2} \\
(\mathrm{cmol} \\
\left.\mathrm{kg}^{-1}\right)\end{array}$ & $\mathrm{pH}$ & $\begin{array}{l}\text { CEC } \\
(\mathrm{cmol} \\
\left.\mathrm{kg}^{-1}\right)\end{array}$ & $\begin{array}{l}\mathrm{NO}_{3}^{-}-\mathrm{N} \\
(\mathrm{mg} \\
\left.\mathrm{kg}^{-1}\right)\end{array}$ & $\begin{array}{l}\mathrm{SO}_{4}^{-2}-\mathrm{S} \\
(\mathrm{mg} \\
\left.\mathrm{kg}^{-1}\right)\end{array}$ & $\begin{array}{l}\mathrm{Zn}^{+2} \\
(\mathrm{mg} \\
\left.\mathrm{kg}^{-1}\right)\end{array}$ & $\begin{array}{l}\mathrm{Mn}^{+2} \\
(\mathrm{mg} \\
\left.\mathrm{kg}^{-1}\right)\end{array}$ & $\begin{array}{l}\mathrm{Fe}^{+2} \\
(\mathrm{mg} \\
\left.\mathrm{kg}^{-1}\right)\end{array}$ & $\begin{array}{l}\mathrm{Cu}^{+2} \\
(\mathrm{mg} \\
\left.\mathrm{kg}^{-1}\right)\end{array}$ & $\begin{array}{l}\mathrm{EC}_{1: 2.5} \\
(\mathrm{dS} \\
\left.\mathrm{m}^{-1}\right)\end{array}$ \\
\hline \multirow{3}{*}{ F1 } & Low & 120.98 & $\begin{array}{l}2.91 \\
\mathrm{a}\end{array}$ & 9.79 & 2.34 & $2.51 \mathrm{~b}$ & $5.93 \mathrm{~b}$ & $0.09 \mathrm{~b}$ & $\begin{array}{l}6.26 \\
b\end{array}$ & $\begin{array}{l}14.51 \\
\text { b }\end{array}$ & 50.56 & 10.5 & $\begin{array}{l}1.18 \\
\mathrm{a}\end{array}$ & $\begin{array}{l}65.12 \\
a\end{array}$ & $\begin{array}{l}145.52 \\
\mathrm{a}\end{array}$ & $\begin{array}{l}1.11 \\
a\end{array}$ & $0.8 \mathrm{~b}$ \\
\hline & Medium & 120.63 & $\begin{array}{l}2.57 \\
\mathrm{a}\end{array}$ & 8.03 & 2.31 & $3.17 \mathrm{~b}$ & $6.9 \mathrm{a}$ & $0.12 \mathrm{~b}$ & $\begin{array}{l}6.27 \\
b\end{array}$ & $\begin{array}{l}16.88 \\
\text { b }\end{array}$ & 42.91 & 8.46 & $\begin{array}{l}0.84 \\
b\end{array}$ & $\begin{array}{l}46.78 \\
\text { b }\end{array}$ & $\begin{array}{l}124.25 \\
b\end{array}$ & $\begin{array}{l}1.11 \\
\mathrm{a}\end{array}$ & $0.8 \mathrm{~b}$ \\
\hline & High & 120.12 & $\begin{array}{l}1.96 \\
b\end{array}$ & 8.44 & 2.55 & $3.49 \mathrm{a}$ & $7.54 \mathrm{a}$ & $0.23 \mathrm{a}$ & $\begin{array}{l}6.78 \\
a\end{array}$ & $\begin{array}{l}19.95 \\
\mathrm{a}\end{array}$ & 50.74 & 10.78 & $\begin{array}{l}0.73 \\
b\end{array}$ & $\begin{array}{l}34.48 \\
\text { b }\end{array}$ & $\begin{array}{l}114.56 \\
b\end{array}$ & $\begin{array}{l}0.82 \\
b\end{array}$ & $1.5 \mathrm{a}$ \\
\hline \multirow{3}{*}{ F2 } & Low & 121.29 & $\begin{array}{l}3.19 \\
a\end{array}$ & 21.42 & 2.50 & $2.55 \mathrm{~b}$ & $7.28 \mathrm{~b}$ & $0.07 \mathrm{~b}$ & $\begin{array}{l}6.17 \\
b\end{array}$ & $\begin{array}{l}15.72 \\
\text { b }\end{array}$ & 60.53 & 15.19 & $2.0 \mathrm{a}$ & $\begin{array}{l}63.94 \\
\mathrm{a}\end{array}$ & $\begin{array}{l}119.67 \\
\mathrm{a}\end{array}$ & $\begin{array}{l}1.15 \\
a\end{array}$ & $0.6 \mathrm{~b}$ \\
\hline & Medium & 120.98 & $\begin{array}{l}2.99 \\
a\end{array}$ & 10.37 & 1.93 & $2.71 \mathrm{~b}$ & $\begin{array}{l}7.65 \\
\mathrm{ab}\end{array}$ & $0.08 \mathrm{~b}$ & $6.3 \mathrm{~b}$ & $\begin{array}{l}17.06 \\
b\end{array}$ & 67.38 & 15.34 & $\begin{array}{l}1.24 \\
b\end{array}$ & $45.7 \mathrm{~b}$ & $\begin{array}{l}107.54 \\
\text { b }\end{array}$ & $\begin{array}{l}1.09 \\
b\end{array}$ & $0.7 \mathrm{~b}$ \\
\hline & High & 120.56 & $\begin{array}{l}2.25 \\
b\end{array}$ & 15.44 & 2.30 & $3.05 \mathrm{a}$ & $8.95 \mathrm{a}$ & $0.18 \mathrm{a}$ & $\begin{array}{l}6.75 \\
a\end{array}$ & $\begin{array}{l}20.83 \\
a\end{array}$ & 71.96 & 15.59 & $\begin{array}{l}1.12 \\
b\end{array}$ & $\begin{array}{l}38.71 \\
b\end{array}$ & $\begin{array}{l}101.39 \\
b\end{array}$ & $\begin{array}{l}0.89 \\
b\end{array}$ & $1.18 \mathrm{a}$ \\
\hline
\end{tabular}

SOM: soil organic matter, CEC: cation exchange capacity, $\mathrm{EC}_{1: 2.5}$ : laboratory-measured electrical conductivity. $\mathrm{a}-\mathrm{b}$ The same letters indicate no significant differences $(P \leqslant 0.05)$ for each site.

${ }^{a} \mathrm{EL}$ : Average elevation for each $\mathrm{EC}_{\mathrm{a}}$ zone.
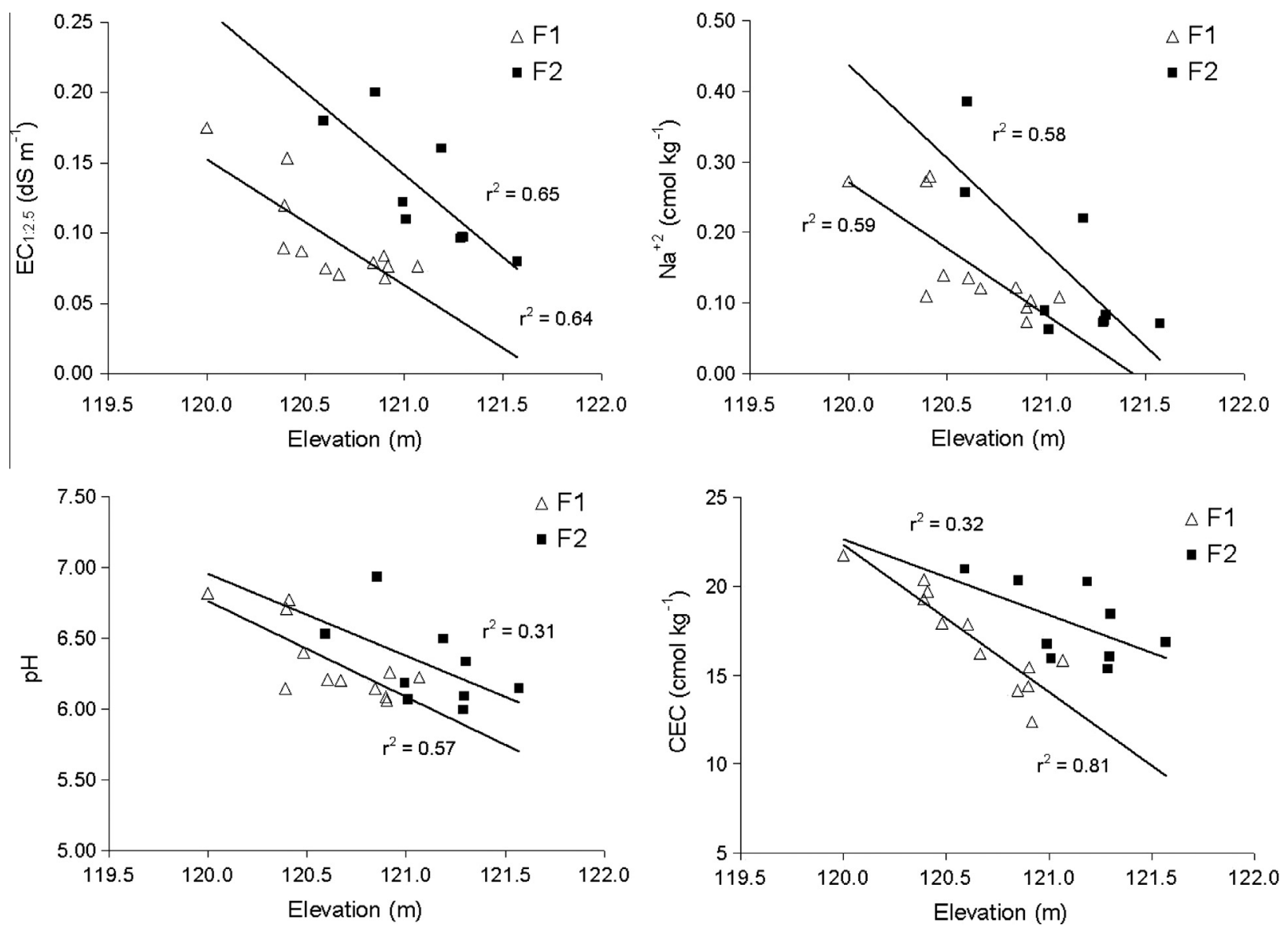

Fig. 4. Elevation vs. $\mathrm{EC}_{1: 2.5}, \mathrm{Na}^{+2}, \mathrm{pH}$ and $\mathrm{CEC}$ in each field. The coefficient of determination $\left(r^{2}\right)$ is given for simple linear regressions.

directly, it has the potential to identify HMZ with differing productivity and nutrient requirements.

\section{Conclusions}

The results of this study indicate that for both fields, the PCstepwise regression analysis was able to account for $>50 \%$ of the variability in the $\mathrm{EC}_{\mathrm{a}}$. Principal-component groups consisting of all soil properties (mainly $\mathrm{EC}_{1: 2.5}$ and $\mathrm{pH}$ ) and some exchange cat- ions $\left(\mathrm{Zn}^{+2}, \mathrm{Ca}^{+2}, \mathrm{Mg}^{+2}, \mathrm{Mn}^{+2}, \mathrm{Na}^{+}, \mathrm{Fe}^{+2}\right.$ and $\left.\mathrm{Cu}^{+2}\right)$ were able to consistently account for the spatial variability of the $\mathrm{EC}_{\mathrm{a}}$. In contrast, the PC-stepwise regression analysis was not able to consistently identify models that accounted for other soil nutrients $\left(\mathrm{K}^{+}, \mathrm{P}\right.$, $\mathrm{NO}_{3}^{-}-\mathrm{N}$ and $\mathrm{SO}_{4}^{-2}-\mathrm{S}$ ). $>$ This does not mean that $\mathrm{EC}_{\mathrm{a}}$ has no value in determining nutrient levels in the soil. Instead, this study shows that $\mathrm{EC}_{\mathrm{a}}$ could be a valuable tool when used in conjunction with multivariate statistical procedures in identifying some soil properties and nutrient content. 
The $\mathrm{K}^{+}, \mathrm{P}, \mathrm{NO}_{3}^{-}-\mathrm{N}$ and $\mathrm{SO}_{4}^{-2}-\mathrm{S}$ ), content had low values and few differences in average in the different classes of $\mathrm{EC}_{\mathrm{a}}$, so it would not be advisable to create management zones based on these nutrients. However, $\mathrm{EC}_{\mathrm{a}}$ measurements successfully delimited two homogeneous soil zones associated with the spatial distribution of all soil properties and $\mathrm{Zn}^{+2}, \mathrm{Ca}^{+2}, \mathrm{Mg}^{+2}, \mathrm{Mn}^{+2}, \mathrm{Na}^{+}, \mathrm{Fe}^{+2}$ and $\mathrm{Cu}^{+2}$ concentrations.

Considering that CEC, SOM content and $\mathrm{pH}_{\mathrm{s}}$ values are static over time and are used to determine soil fertility, these results suggest that $\mathrm{EC}_{\mathrm{a}}$ field-scale maps in areas with well-drained soil (Entic Haplustoll) and moderate to imperfect-drainage soil, moderately saline-alkali in depth (Typic Calciacuoll, Typic Natralboll), can delimit two zones which are homogeneous enough to serve as meaningful zones for management and sampling purposes, without sacrificing soil spatial variability information.

In the next few years, some studies will be conducted to evaluate these subfield management zones, using yield maps to better understand the agronomic significance of this classification.

\section{Acknowledgements}

We would like to thank Mauricio Simón, Julian Muguerza and Sebastian Storti for their help in gathering the data on the fields where the study was conducted. The experiment was conducted with funding from AGD (Aceitera General Deheza) and INTA Project, AEAI3722. At the same time, we would like express our appreciation to the CONICET (postgraduate fellowship program of National Council of Scientific and Technical Research).

\section{References}

Bosch Mayol, M., Costa, J.L., Cabria, F.N., Aparicio, V., 2012. Relación entre la variabilidad espacial de la conductividad eléctrica y el contenido de sodio del suelo. Ciencia del suelo. 30 (2), 95-105.

Bullock, D.S., Kitchen, N., Bullock, D.G., 2007. Multidisciplinary teams: A necessity for research in precision agriculture systems. Crop Sci. 47, 1765-1769.

Bremner, J.M., 1965. Inorganic forms of nitrogen. In: Black, C.A. (Ed.), Methods of soil analysis, Madison, Wisconsin, USA, pp. 1179-1237.

Chapman, H.D., 1965. Cation-exchange capacity. In: Black, C.A. (Ed.), Methods of soil analysis - Chemical \& microbiological properties. Agronomy 9, pp. 891-901.

Corwin, D.L., Lesch, S.M., 2003. Application of soil electrical conductivity to precision agriculture: theory, principles, and guidelines. Agron. J. 95 (3), 455471.

Corwin, D.L., Lesch, S.M., 2005. Apparent soil electrical conductivity measurements in agriculture. Comput. Electron. Agric. 46, 11-43.

Corwin, D.L., Lesch, S.M., Oster, J.D., Kaffka, S.R., 2006. Monitoring managementinduced spatio-temporal changes in soil quality through soil sampling directed by apparent electrical conductivity. Geoderma 131, 369-387.

Eriksen, J., 1997. Sulphur cycling in Danish agricultural soils: inorganic sulphate dynamics and plant uptake. Soil Biol. Biochem. 29, 1379-1385.

ESRI, 2001. Using ArcGIS Geostatistical Analyst. ESRI, Redlands, CA.

Eyherabide, M.H., Sainz Rozas, H., Echeverría, H., Velasco, J., Barraco, M., Ferraris, G., Angelini, H., 2012. Niveles de cinc disponibles en suelos de la región pampeana Argentina. XIX Congreso Latinoamericano de la ciencia del suelo. XXIII Congreso Argentino de la ciencia del suelo.

Farahani, H.J., Flynn, R.L., 2007. Map quality and zone delineation as affected by width of parallel swaths of mobile agricultural sensors. Prec. Agric. 96 (2), $151-$ 159.

Gambaudo, S., Fontanetto, H., Beccria, G., Boretto, D., Albrecht, J., Tron, L., 2008. Recuperación de suelos halomorficos mediante la Agricultura de Precisión. Información técnica de cultivos de verano. Publicación Miscelánea n 112.

Ghida Daza, C., Sánchez, C., 2009. Zonas agroeconómicas homogéneas Córdoba. Buenos Aires. INTA. Serie: Estudios socioeconómicos de la sustentabilidad de los sistemas de producción y recursos naturales, p. 257.

Groenigen, J.W., Gah, M., Bouma, J., 2000. Soil sampling strategies for precision agriculture research under sahelian conditions. Soil Sci. Soc. Am. J. 64, 16741680.

Heiniger, R.W., Mcbride, R.G., Clay, D.E., 2003. Using soil electrical conductivity to improve nutrient management. Agron. J. 95, 508-519.

Institute, S.A.S., 2002. SAS User's Guide. Statistical Analysis System Institute Inc., Cary, NC.
INTA, 1986. Carta de Suelos de la Republica Argentina - Hoja 3363-28 - Canals Plan Mapa de Suelo - Cordoba, escala 1:50000.

Isaaks, E.H., Srivastava, R.M., 1989. An introduction to Applied Geostatistics. Oxford University Press, New York, NY, p. 561.

Jung, W.K., Kitchen, N.R., Sudduth, K.A., Kremer, R.J., Motavalli, P.P., 2005. Relationship of apparent soil electrical conductivity to claypan soil properties. Soil Sci. Soc. Am. J. 69, 883-892.

Kaffka, S.R., Lesch, S.M., Bali, K.M., Corwin, D.L., 2005. Site-specific management in salt-affected sugar beet fields using electromagnetic induction. Comput. Electron. Agri. 46, 329-350.

Kitchen, N.R., Drummond, S.T., Lund, E.D., Sudduth, K., Buchleiter, K.A., 2003. Soil electrical conductivity and topography related to yield for three contrasting soil-crop systems. Agron. J. 95, 483-495.

Kitchen, N.R., Sudduth, K.A., Myers, D.B., Drummond, S.T., Hong, S.Y., 2005 Delineating productivity zones on claypan soil fields using apparent soil electrical conductivity. Comp. Electron. Agric. 46, 285-308.

Kravchenko, A.N., Bullock, D.G., 2002. Quantitative mapping of soil drainage classes using topographical data and soil electrical conductivity. Crop Sci. 66, 235-243.

Malicki, M.A., Walczak, R.T. 1999. Evaluating soil salinity status from bulk electrical conductivity and permittivity. Eur. J. Soil Sci. 50 (3), 505-514.

Marques da Silva, J.R., Silva, L.L., 2008. Evaluation of the relationship between maize yield spatial and temporal variability and different topographic attributes. Biosyst. Eng. 101, 183-190.

Mehlich, A., 1984. Mehlich-3 soil test extractant: a modification of Mehlich-2 extractant. Commun. Soil Sci. Plant Anal. 15 (12), 1417-1422.

Moral, F.J., Terrón, J.M., Marques Da Silva, J.R., 2010. Delineation of management zones using mobile measurements of soil apparent electrical conductivity and multivariate geostatistical techniques. Soil Tillage Res. 106, 335-343.

Moral, F.J., Terrón, J.M., Rebollo, F.J., 2011. Site-specific management zones based on the Rasch model and geostatistical techniques. Comput. Electron. Agri. 75, 223230.

Motavalli, P.P., Udawatta, R.P., Bardhan, S., 2013. Apparent soil electrical conductivity used to determine soil phosphorus variability in poultry litteramended pastures. Am. J. Exp. Agric. 3 (1), 124-141.

Peralta, N.R., Costa, J.L., Balzarini, M., Angelini, H., 2013. Delineation of management zones with measurements of soil apparent electrical conductivity in the southeastern pampas. Can. J. Soil Sci. 93, 205-218.

Rhoades, J.D., Corwin, D.L., 1990. Soil electrical conductivity: effects of soil properties and application to soil salinity appraisal. Commun. Soil Sci. Plant Anal. 21, 836-860.

Rhoades, J.D., Manteghi, N.A., Shouse, P.J., Alves, W.J., 1989. Soil electrical conductivity and soil salinity: new formulations and calibrations. Soil Sci. Soc. Am. J. 53, 433-439.

Secretaría de Agricultura, Ganadería, Pesca y Alimentos (SAGPyA), 2009. Zonas agroeconómicas homogéneas Córdoba. Buenos Aires. <http:// www.sagpya.mecon.gov.ar/> (15.03.12).

Serrano, J.M., Peça, J.O., Marques Da Silva, J.R., Shaidian, S., 2010. Mapping soil and pasture variability with an electromagnetic induction sensor. Comput. Electron. Agric. 73, 7-16.

Shainberg, I., Rhoades, J.D., Prather, R.J., 1980. Effect of changeable sodium percentage, cation exchange capacity, and soil solution concentration on soil electrical conductivity. Soil Sci. Soc. Am. J. 44, 469-473.

Shi, J., Xu, J., Huang, P., 2008. Spatial variability and evaluation of status of micronutrients in selected soils around Taihu Lake, China. J. Soils Sediments 8, 415-423.

Shuman, L.M., 1991. Chemical forms of micronutrients in soils. In: Mortvedt, J.J., Cox, F.R., Shuman, L.M., Welch, M.R. (Eds.), Micronutrients in agriculture, Madison, Winsconsin, USA, pp. 113-144.

Sudduth, K.A., Kitchen, N.R., Bollero, G.A., Bullock, D.G., Wiebold, W.J., 2003. Comparison of electromagnetic induction and direct sensing of soil electrical conductivity. Agron. J. 95, 472-482.

Sudduth, K.A., Kitchen, N.R., Wiebold, W.J., Batchelor, W.D., Bollero, G.A., Bullock, D.G., Clay, D.E., Palm, H.L., Pierce, F.J., Schuler, R.T., Thelen, K.D., 2005. Relating apparent electrical conductivity top soil properties across the North-Central USA. Comp. Electron. Agric. 46, 263-283.

Tripathi, S., Kumari, S., Chakraborty, A., Gupta, A., Chakrabarti, K., Bandyapadhyay B.K., 2006. Microbial biomass and its activities in salt-affected coastal soils. Biol. Fertil. Soils 42, 273-277.

Veris Technologies, 2001. Frequently asked questions about soil electrical conductivity. Veris Technologies, Salina. KS. <http://www.veristech.com> (accessed 25.07.12).

Walkley, A., Black, I.A., 1934. An examination of Degtjareff method for determining soil organic matter and a proposed modification of the chromic acid titration method. Soil Sci. 37, 29-37.

Wilding, L.P., Bouma, J., Goss, D.W., 1994. Impact of spatial variability on interpretive modeling. In: Bryant, R.B., Arnold, R.W. (Eds.), Quantitative modeling of soil forming processes. SSSA Spec. Publ. 39. ASA, CSSA, and SSSA, Madison, WI, USA, pp. 61-75. 